\title{
ONE PROOF OF THE GHEORGHIU INEQUALITY
}

\author{
BOŽIDAR IVANKOVIĆ
}

Abstract. The Gheorghiu inequality is a reverse Hölder's inequality. In this article, the Gheorghiu inequality is proven by using a property of a two - variable function. Original Gheorghiu's result is presented and compared with obtained result.

Mathematics subject classification (2010): 26D15, 26D99.

Keywords and phrases: Convex functions, linear functionals, Jensen's inequality, reverse Jessen's inequality, reverse Hölder's inequality, Gheorghiu inequality.

\section{REFERENCES}

[1] V. CSISZÁR AND T. F. MóRI, The convexity method of proving moment-type inequalities, Statistics and Probability Letters 66, 1 (2004), 303-313.

[2] V. ČUlJak, B. IVAnković And J. E. PeČARIĆ, On Jensen-McShane's inequality, Periodica Mathematica Hungarica 58, 2 (2009), 139-154.

[3] B. IVAnković, S. Izumino, J. E. Pečarić and M. Tominaga, On Jensen-McShane's inequality, Journal of Inequalities in Pure and Applied Mathematics 8, 3 (2007), 88-97.

[4] B. IVAnKović, Konverzije i poboljšanja Jensenove nejednakosti za funkcije više varijabli, Doctoral thesis Zagreb, 2010 (croatian).

[5] S. IZUMino AND M. Tominaga, Estimations in Hölder's type inequalities, Mathematical Inequalities and Applications 4, 1 (2001), 163-187.

[6] J. Matkows KI, A Converse of the Hölder Inequality Theorem Mathematical Inequalities and Applications, 12, 1 (2009), 21-32.

[7] D. Mitrinović, J. E. PeČArić And A. M. Fink, Classical and New Inequalities in Analysis, Kluwer. Acad. Pub., Boston Dordrecht, 1993.

[8] J. E. Pečarić, F. Proschan, And Y. L. Tong, Convex Functions, Partial Orderings, and Statistical Applications, Academic Press, Inc. San Diego, 1992.

[9] M. Serban And A. Gheorghiu, Note sur une Inégalité de Cauchy, Bull. Math. Soc. Rommaine des Sciences 35, 1 (1933), 117-119. 